DOI: 10.34015/2523-4552.2019.3.09

УДК 340.12+342.731(37)

Цвєткова Ю. В., кандидат юридичних наук, доцент, доцент кафедри історії права та держави юридичного факультету Київського національного університету імені Тараса Шевченка ORCID ID: 0000-0001-7557-7048

\title{
ОСОБЛИВОСТІ РИМСЬКОЇ ПРАВОСВІДОМОСТІ В РЕСПУБЛІКАНСЬКИЙ ПЕРІОД ЯК ЧИННИК РЕЛІГІЙНОЇ ТОЛЕРАНТНОСТІ
}

У статті розглядаються особливості формування толерантного ставлення до інших релігій у колективній правосвідомості титульної більшості населення античного Риму. Відстоюється позиція, що релігійна толерантність була притаманна загальним поглядам та культурі римської полісної громади, що відобразилось у їі правовій системі та позитивно вплинуло на розширення кордонів держави, налагодження взаємин з населенням приєднаних територій через гарантування їм свободи віросповідання, зниженням соціального напруження у суспільстві тощо. В подальшому через рецепцію римського права ця особливість правосвідомості буде закладена у підвалини західної традиції права, а в модерний період вплине на формування комплексу невід'ємних прав людини.

Ключові слова: колективна правосвідомість; свобода віросповідання; правовий інститут релігійної толерантності; Античний Рим.

Статья рассматривает особенности формирования толерантного отношения к чужим религиям в коллективном правосознании титульного большинства населения античного Рима. Отстаивается позиция, что религиозная толерантность была свойственна общим взглядам и культуре римской полисной общины, что отобразилось в ее правовой системе и позитивно повлияло на расширение границ государства, налаживание взаимоотношений с населением присоединенных территорий через гарантирование им свободы вероисповедания, снижением социального напряжения в обществе. В дальнейшем через рецепцию римского права эта особенность правосознания будет заложена в основы западной традиции права, а в модерный период повлияет на формирование комплекса неотъемлемых прав человека.

Ключевые слова: коллективное правосознание; свобода вероисповедания; правовой институт религиозной толерантности; Античный Рим.

Постановка проблеми. Римська держава в історії права є унікаль- ним явищем. За час свого існування вона з маленького поліса перетвори- 
лася на світову державу та протягом тривалого часу в складних економічних, правових, інфраструктурних та соціальних умовах стародавнього періоду змогла втримати свою цілісність. В західній традиції права до наших днів жодна з держав не змогла об'єднати в своїх кордонах навіть половину від тих територій, які зібрав під своє управління античний Рим. Правові механізми та суспільноправові інститути, завдяки яким Римська державність досягла такого результату залишаються предметом наукових інтересів сучасних юристів. Одним із явищ, важливих в той час та дуже актуальних сьогодні, $є$ релігійна толерантність у полірелігійних суспільствах, механізми їі впровадження до правових систем держав та правосвідомості населення та зменшення впливу релігій меншості на відцентрові процеси в державному будівництві та суспільному добробуті. Протягом більшості часу свого існування, римське суспільство успішно демонструвало таку релігійну толерантність щодо народів, включених до складу своєї федеративної держави, забезпечуючи їх свободу віросповідання та, таким чином, зменшуючи соціальну напругу і компенсуючи їм втрату самостійності. У багатьох сучасних держав у складі територій наявні подібні етнічні анклави, населення яких сповідує власну релігію. Розвиток релігійної толерантності в правосвідомості населення цих держав, подібно до давньоримського досвіду, може відігравати важливу роль у збереженні їх цілісності та підвищенні дотримання прав людини. Усвідомлення шляхів та механізмів закріплення релігійної толерантності у правосвідомості населення античного Риму дає можли- вість не тільки побачити генезу цього явища, але й використати його у сьогоднішній час глобалізаційних та відцентрових тенденцій у розвитку держав та їх правових систем.

Аналіз останніх досліджень та публікацій. Теоретичні та практичні аспекти інституту правосвідомості, механізм його поширення активно досліджувався сучасними теоретиками права, зокрема такими як О. Данильян, Ю. Дмитрієнко, О. Деменко, Д. Єрмоленко, Ю. Калиновський, М. Кельман, М. Козюбра, А. Колодій, В. Коновалова, С. Кравченко, Л. Кушинська, П. Рабинович, I. Омельчук, О. Скакун, С. Сливка, В. Тимошенко, I. Тімуш, М. Цимбалюк, О. Цуркан, А. Штанько. Ці праці становлять теоретичну та методологічну основу нашого дослідження. Більшість дослідників ставлення античного римського суспільства до релігійної сфери є істориками, зокрема найвідомішими серед них $\epsilon$ праці Д. Крюкова, П. Лашкарева, I. Маяк, I. Свенцицької, О. Штаєрман. Зазначені автори розглядають здебільшого історичні та культурні аспекти розвитку релігії в Римі, зосереджуючись або на державній політеїстичній релігії самого Риму або на християнстві. Проте, їхні дослідження не аналізують правовий аспект формування ставлення більшості титульного населення до недержавних релігій меншості, що, на нашу думку, і повинно в повній мірі продемонструвати розвиток релігійної толерантності у римському суспільстві та праві та показати вплив наявності цього явища у правосвідомості на доцентрові державні процеси та суспільно-політичний добробут.

Постановка завдання. Автор ставить за мету проаналізувати ку- 
льтурні, історичні, соціальні та державно-правові фактори, що вплинули на формування в правосвідомості римлян толерантного ставлення до релігій інших народів, зокрема тих, що увійшли до складу римської держави в статусі федератів.

Виклад основного матеріалу. Формування правової системи та основних державно-правових інститутів грунтується на комплексі загальних суспільних явищ правової культури активної більшості соціуму, які, в свою чергу, напряму виходять із колективної правосвідомості. Теоретичне обгрунтування правосвідомості зводиться до сукупності оціночних думок та настанов, що визначають ставлення суб'єктів соціальних відносин (соціальних груп, страт, окремого громадянина або суспільства загалом) до права й чинного законодавства, а також практика його застосування, правових звичаїв, ціннісних орієнтацій, які регулюють людську поведінку в юридично значущих ситуаціях [1, c. 425]. Правосвідомість відображає правову дійсність, що склалася за конкретно-історичних умов у тій чи іншій країні, але водночас впливає на функціонування й розвиток правової системи. Так, правосвідомість суспільства поєднує як аксіологічний вимір (домінантні правові цінності для певного типу суспільства), так і онтологічний вимір - способи та форми буття правосвідомості у конкретно історичних умовах, грунтується на комунікативноціннісному тлі, яке утворилося в тому або іншому суспільстві й являє собою усталені уявлення про добро та зло, справедливе й несправедливе, дозволене й недозволене, традиційне і нетрадиційне [2, с. 14].
Невід'ємною запорукою формування релігійної толерантності в суспільстві виступають сформовані у суспільній правосвідомості аксіологічні доктрини позитивного сприйняття різноманітності інших народів та культур, відсутність релігійного зелотизму тощо. Величезним чинником стає закладення у соціумі ідеї компромісності, готовності поступитися особистими уподобаннями заради великої мети добробуту держави та суспільства. Ці чинники в повній мірі були реалізовані у правосвідомості населення античного Риму в республіканський період.

Грунт для формування цієї особливості римської правової культури у вигляді забезпечення з боку пануючого народу релігійної свободи суб'єктам федерації, які були включені до складу Римської держави, була закладена у першопочатковому толерантному ставленні римських патриціїв до релігійного різноманіття своїх співвітчизників ще у царський період (754-509 рр. до н.е.) Заснований чужинцями, Рим не міг заперечувати існування релігій своїх сусідів навіть після їхнього підкорення, адже на самій його території серед його громадян існували два пантеони. У 445 р. до н.е., тобто у період ранньої республіки, коли більшість правових інститутів ще зберігалися з попереднього періоду, Тит Лівій описує заворушення, що почалися в Римі при спробі прийняти закон про дозвіл укладання шлюбів між патриціями та плебеями. Одним із аргументів проти цього закону став аргумент що новоутворені родини та народжені в них діти не будуть знати «... чиїм святиням вони моляться...» та, як наслідок «...божеський та людський порядки 
змішаються...» [3, с. 218] Така аргументація є свідченням того, що в самому Римі пантеони патриціїв та плебеїв не співпадали. Деякі дослідники вважають, що ця відмінність пантеонів патриціїв та плебеїв пояснюється тим, що серед останніх було багато етрусків. [4, с. 36] Не заперечуючи цієї думки, мусимо, однак зазначити, що у 445 р. до н.е. етруська державність ще була у розквіті, і переселенці в Рим хоча й могли становити певний відсоток серед плебеїв, але не були абсолютною більшістю. Отже, навіть патронно-клієнтські відносини патриціїв та плебеїв у Римі, які пронизували усе римське суспільство в періоди ранньої республіки та царів (рексів) залишали вибір віросповідання виключно приватною сферою клієнта. Таким чином, відмінність релігії патриціїв та плебеїв була традиційним фактором, що склався з самого початку та формував у римлян психологічну готовність не заперечувати існування інших віросповідань на своїх теренах, були відсутні релігійні ксенофобські настрої та зелотизм. Це призвело до того, що певний рівень релігійної свободи із самого початку був характерною рисою для Давньоримської держави.

Надалі специфіка римської правосвідомості у релігійному питанні обумовила свобода віросповідання для тих народів та племен, що входили до складу Римської держави на правах суб’єктів федерації. Дослідники римського права вважають, що «...римляни вважали неможливим існування розвинутого суспільства, яке б поважало стосунки та цінувало справедливість й добросовісність без віри у богів...» [5, с. 9-10]. Однак, найбільша відмінність римської ду- мки до IV ст. (тобто до поширення християнства та набуття ним статусу державної релігії) від концепцій інших держав стародавнього та феодального світу полягала в тому, що римляни у своїй правосвідомості ототожнювали богів з існуванням ладу у суспільстві, а не з існуванням самої держави. У більшості інших держав стародавнього та феодального періоду захоплення та приєднання сусідніх територій практично вимагало у завойовників змінити місцевий пантеон підкорених, навернути їх у свою віру та, таким чином знищити їхніх богів як ототожнення їхньої незалежності та державності. Така жорстка релігійна реформа часто відбувалася одночасно зі стратою представників місцевої правлячої династії й обидві дії символізували знищення незалежності й неможливість їі повернення у майбутньому: завоювання ніби відбувалося на усіх рівнях - територіальному, у вигляді фактичного захоплення земель, людському обезголовлення правлячої верхівки та небесному - знищення пантеону.

Римська правосвідомість у цьому питанні відрізнялася по всіх трьох позиціях, адже психологія мешканця ремісничо-торгівельного поліса звертала увагу не на фактичне володіння землею, а на контроль економічних потоків; республіканські концепції виборного формування вищих державних органів нівелювали роль династій царів як суверенів, отже, в більшості випадків, й не мало радикальної потреби у їхньому фізичному знищенні. Місцевим богам віддавалась функція опіки не над державністю, а над благоустроєм місцевих земель та суспільства - в чому були зацікавлені й самі римляни щоб отримувати $з$ цих територій 
переваги та прибутки. На їхню думку, знищення віри в богів, які опікувалися певною територією, призводило до катаклізмів та негараздів, починаючи від неврожаїв та закінчуючи виверженнями вулканів та іншими стихійними лихами.

Обмеження сповідання місцевих релігій відбувалося тільки тоді, коли їхнє існування загрожувало самому Риму та основам римського суспільства, як це було із забороною культу Діонісу Senatus consultum de Bacchanalibus [6; 3, 39.17] за кримінальні правопорушення та оргії його вірян або релігії гало-кельтських друїдів за людські жертвопринесення [7, Кл. 25.5].

Не слід ігнорувати й той факт, що початкова релігійно-філософська доктрина римської релігії включає до родового пантеону предків - ларів та пенатів, які надають покровительство роду та опікуються ним [8, c. 439-440], щодо яких вчиняються спеціальні ритуали «sacra gentiliciia», в яких могли брати участь тільки агнати [8, с. 397]. Такий підхід з самого початку готував римлян до прийняття існування інших богів на інших територіях, адже предки у кожного роду були власні, і вимагати від чужинців вшанування предків свого роду було як мінімум дивно, а як максимум не результативно, адже чужі предки не будуть допомагати вам, а ваші - чужинцям.

У процесі збільшення території Римської держави перед римлянами постала загроза втрати своєї ідентичності, свого суспільного ладу, організаційних принципів, культури та правової системи - тобто усього того суспільного та державно-правового благоустрою, який, на їхню думку, призвів до процвітання Римської держави та знаходився під опікою богів власного римського пантеону. Саме тому, дозволяючи вільне сповідування інших релігій, римляни не відмовлялися від своєї та намагалася обмежити поширення чужих культів у самому Римі, а потім в Італії, на яку разом із правом громадянства вони поширили в цей період своє усвідомлення «титульних», корінних земель. Вірність власному пантеону не заперечувала для римського громадянина можливості звернутися до місцевих богів завойованих народів, особливо тоді, коли поточна діяльність громадянина була пов'язана із цією територією чи народом, тобто, на думку римлянина, сферою впливу місцевих богів.

Римська традиція релігійної толерантності напряму виходила із притаманної розвинутій культурі античності інтелектуальної мобільності та готовності сприймати те нове, що може принести користь. Саме цією особливістю правосвідомості можна пояснити прагнення римлян ототожнити богів інших пантеонів із своїми власними, а незнайомих, але «корисних» богів перенести до римського пантеону. Так відбулося ототожнення з римським практично всього грецького пантеону, цілої низки італійських богів та запозичення, наприклад, у галлів богині конярства Епони, яка стала в Римі покровителькою вищого прошарку суспільства - вершників. Але такий процес ототожнення та запозичення впливав і на ставлення римлян до сповідання релігій, боги яких не потрапили до переліку ототожнених та запозичених. Процес розширення римського пантеону відбувався постійно, і сьогодні «чужі» релігії федератів завтра могли набути ста- 
тус державних. Як наслідок, підсвідомо римляни ставилися до чужих віровчень 3 повагою, якщо тільки доктрини та догми цих релігій не суперечили основним принципам римського права.

Значну роль у становленні свободи віросповідання римських федератів становив зверхнений підхід римлян до інших народів. Навіть при наданні громадянства, виборчих прав «jus suffragio» та права укладати шлюб 3 римлянами «јus connubii» населенню приєднаних територій, римська правова доктрина та правосвідомість встановлювали відстань щодо них. Початковий суспільний поділ римської громади «civitas» квірити - не-квірити з часом трансформувався у римляни - латини, потім у римляни - латини - перегрини. Гай Октавіан Август зазначав, що йому простіше звільнити особу з федератів від податків, створивши збиток для державної скарбниці, ніж надати їй статус громадянина, адже це $\epsilon$ «приниження честі римських громадян» [7, Авг 38.3].

Висновки. Розвиток Давньоримської держави та їі панування над захопленими чи приєднаними територіями формувало концепції ідеалізування та досконалості римської державності, правової системи, культури та традицій, їхньої зверхненості над усіма аналогічними явищами інших народів, появою того, що у сьогоденні класифікується як «імперська» правосвідомість. Але унікальною особливістю цього явища у Римі було те, що на відміну від багатьох інших імперських державних утворень, визнаючи власну зверхненість, римляни не ставили собі за мету змінювати інші народи під свої стандарти, а навпаки, проводили розмежування та наполягали на нетотожності. Релігійна свобода федератів до IV ст. використовувалася Римом для цієї мети, встановлюючи одну з ідентифікаційних меж. Особливості формування римської правосвідомості щодо регулювання релігійних правовідносин реалізувалося у правовому інституті релігійної толерантності, який в подальшому, через рецепцію римського права та культури буде закладений у підвалини західної традиції права, а в модерний період увійде до комплексу невід'ємних прав людини.

\section{Список використаних джерел}

1. Попадинець Г. О. Правосвідомість і правова культура як чинники становлення громадянського суспільства. Львів : Видавництво Львівської Політехніки, 2006. С. 422-427.

2. Калиновський Ю. Ю. Правосвідомість українського суспільства: ґенеза та сучасність : монографія. Харків : Право, 2008. 288 с.

3. Ливий Тит. История Рима от основания города. В 3 т. Москва : «Ладомир», 2005. 793 c.

4. Крюков Д. А. Мысли о первоначальном различии плебеев в религиозном отношении. Пропилеи. Москва : В университетской типографии, 1854. кн. IV, 80 с.

5. Лашкарев П. Отношение Римского государства к религии вообще и к христианству в особенности. Киев : Тип. Еремеева, 1876. 148 с.

6. Senatus consultum de Bacchanalibus. URL: http://www.thelatinlibrary.com/ scbaccanalibus.html (дата звернення 10.11.2019). 
7. Светоний, Гай Транквилл. Жизнь двенадцати Цезарей. Москва : «Азбука», 2015. $480 \mathrm{c}$.

8. Покровский И. А. Лекции по истории римского права. Римське право в університеті Св. Володимира. Кн. 1. Київ : Либідь, 2010. С. 439-440.

\section{References}

1. Popadinec, G. O. (2006). Pravosvidomist i pravova kultura yak chinniki stanovlennya gromadyanskogo suspilstva. Lviv, Vidavnictvo Lvivskoyi Politehniki [in Ukrainian].

2. Kalinovskij, Yu. Yu. (2008). Pravosvidomist ukrayinskogo suspilstva: geneza tasuchasnist : monografiya. Harkiv: Pravo [in Ukrainian].

3. Livij, Tit (2005). Istoriya Rima ot osnovaniya goroda. V 3 t. Moskva: «Ladomir» [in Russian].

4. Kryukov, D. A. (1854). Mysli o pervonachalnom razlichii plebeev $v$ religioznom otnoshenii. Propilei. Moskva: V universitetskoj tipografii [in Russian].

5. Lashkarev, P. (1876). Otnoshenie Rimskogo gosudarstva $k$ religii voobshe $i k$ hristianstvu v osobennosti. Kiev: Tip. Eremeeva [in Russian]. Russian].

6. Svetonij, Gaj Trankvill. (2015). Zhizn dvenadcati Cezarej. Moskva: «Azbuka» [in

7. Pokrovskij, I. A. (2010). Lekcii po istorii rimskogo prava. Rimske pravo v universiteti Sv. Volodimira. Kn. 1. Kiyiv: Libid [in Ukrainian].

Y. Tsvietkova, Ph.D in Law, Assistant Professor, Assistant Professor of Law Faculty in Taras Shevchenko National University of Kyiv

ORCID ID: 0000-0001-7557-7048

\section{Peculiarities of the Legal Awareness in the Ancient Rome's Republican Period as a Factor of the Religious Tolerance}

The article deals with the peculiarities of the forming of a tolerant attitude towards other religions in the collective consciousness of the titular majority of the population of the Ancient Rome. The article supports a view that religious tolerance was inherent in the general views and the culture of the Roman political community, which was reflected in its legal system and had a positive effect on expanding the state's borders, establishing the relations with the population of the annexed territories by guaranteeing their freedom of religion, and reducing the social strains. The development of the Roman state and its domination over the conquered or annexed territories formed the concepts of the idealization and supremacy of the Roman statehood, legal system, culture and traditions, their superiority over all similar phenomena of the other peoples, the emergence of what is now classified as "imperial mentality". But the unique feature of this phenomenon in Rome was that, unlike many other imperial state formations, the Romans did not seek to convert other peoples to their standards, but tended to differentiate and recognize their subjects' identity. Till the IV century the Romans used the religious freedom of the federates to help in setting the religion as one of the identification marks. The peculiarities of the formation of the Roman legal awareness regarding the regulation of the religious relations were realized in the 
legal institute of religious tolerance, which in the future, through the reception of the Roman law and culture, was incorporated into the foundations of the Western tradition of law, and in the modern period was included in the complex of the inalienable human rights.

Keywords: collective legal awareness; freedom of religion; legal institute of religious tolerance; Ancient Rome. 